УДК 347.73

ГРНТИ 10.21.41

\title{
НАЛОГОВАЯ ПРИВЛЕКАТЕЛЬНОСТЬ ГОСУДАРСТВА НА ПРИМЕРЕ НАЛОГА НА ПРИБЫЛЬ ОРГАНИЗАЦИЙ В РОССИЙСКОЙ ФЕДЕРАЦИИ И КИТАЙСКОЙ НАРОДНОЙ РЕСПУБЛИКЕ
}

\author{
(c) 2019 Шаипова Светлана Анатольевна \\ кандидат экономических наук, доцент, \\ адвокат Адвокатской палаты Московской области, Россия, Москва \\ E-mail: shaipovasvetlana@yandex.ru
}

(c) 2019 Тремаскин Игорь Эдуардович

аспирант 2-го года очной формы обучения

Всероссийский государственный университет юстиции (РПА Минюста России), Россия, Москва

В данной статье рассматриваются различия в системе налогообложения Российской Федерации и Китайской Народной Республики. На основании проведенного анализа авторами делаются выводы о влиянии сложившихся систем на инвестиционную привлекательность государств.

Ключевые слова: налогообложение, налоговая привлекательность, налоговая система, административные барьеры, налоговые льготы, налоговый контроль.

В современном обществе с рыночной экономикой тема налогов актуальна при любом виде хозяйственной деятельности физических и юридических лиц. Вопрос налогообложения при внешнеэкономической деятельности затрагивает финансовую систему государства, резиденты которого получают прибыль или сверхприбыль от деятельности на территории чужого государства. Стоит отметить, что актуальность проявляется еще и в том, что в условиях сложных экономических отношений государства объединяются в торговые союзы и максимально эффективно складывают свои ресурсы для наращивания экономической мощи, создания дружественных отношений и получения политического союза с экономическими гигантами. При этом важным остается вопрос о функционировании налоговой системы, ее привлекательности для сотрудничества.

Крупным компаниям, осуществляющим экономическую деятельность на территории другого государства, гораздо выгоднее создавать филиалы по личному закону страны, в которой происходит основная деятельность. Но ключевым нюансом, который может значительно снизить товарооборот, является все же нелабильная налоговая система государств, которые достаточно сильно затрудняют сам процесс оплаты налогов.

В России весьма сложная и запутанная налоговая система. Это понятно из междуна- родного исследования «Уплата налогов» [5]. В данном рейтинге Россия занимает 133 место, а Китай -168 , что само по себе говорит о сложности и малой привлекательности сотрудничества крупных предприятий и концернов. Итоговое место страны определялось по соотношению трех главных показателей - количество налогов, уровень налоговых ставок и время, которое требуется для их уплаты. Например, в Беларуси самое большое в мире количество налогов - 124 , а полная налоговая ставка составляет $145 \%$. Это значит, полная уплата налогов резидентами и нерезидентами делает практически любой бизнес убыточным. В России бизнес уплачивает налоги государству совокупную ставку, кратную $51,4 \%$, что также является достаточно высоким показателем. Сама система уплаты налогов в России значительно сложнее. Это связано с их высоким количеством, запутанной системой и проблемной репутацией.

Данные обстоятельства предоставляют налоговым органам рычаги давления на бизнес и отрицательно сказываются на коммерческой привлекательности государства. Отсюда и низкое место в рейтинге - только 130-е из 178 стран. Налогопривлекательными странами можно назвать офшорные юрисдикции, которые предлагают выгодные условия, при этом не выдают инвесторов и сохраняют коммерческую тайну об инвесторах. Например, Мальдивы, где государство берет с предпринимателей лишь один 
налог в 9,1\%. Помимо офшорных юрисдикций, высокий уровень налоговой привлекательности занимает Королевство Нидерланды, признаваемое государством с самой благоприятной налоговой системой.

Таким образом, налоговая привлекательность государства является важным фактором привлечения в него крупных игроков рынка и денежных потоков. В само понятие налоговой привлекательности следует включить как наличие налоговых льгот, так и уменьшение «административных барьеров», которые являются показателем высокой бюрократизации государства и неспособностью менять законодательство и административный порядок, соответствующий современным деловым отношениям. Говоря о налоговой привлекательности стран, стоит обратиться к положениям п.п. 1 и 2 статьи III ГАТT 1947, из которых следует, что «внутренние налоги и другие внутренние сборы, законы, правила и требования, относящиеся к внутренней продаже, предложениям о продаже, покупке, перевозке, распределению или использованию товаров, не должны применяться к импортированным или отечественным товарам таким образом, чтобы создавать защиту для внутреннего производства» [4]. Товары, происходящие с территории какой-либо договаривающейся стороны и ввозимые на территорию другой, не должны облагаться, прямо или косвенно, внутренними налогами или другими внутренними сборами любого рода, превышающими, прямо или косвенно, налоги и сборы, применяемые к аналогичным товарам отечественного происхождения. Таким образом, страны должны пересмотреть порядок предоставления налоговых льгот и дифференцированные подходы в установлении ставок [3]. Однако необходимо отметить, что не всегда принципы ВТО работают напрямую, иногда чтобы страна устранила нормы, нарушающие это положение, требуется решение, принятое по результатам рассмотрения жалобы через механизм урегулирования споров, предусмотренный ВТО.

В связи с тем, что Россия и Китай образовывают торговый союз, который является одним из крупнейших по товарообороту, нам необходимо произвести анализ по налогу на прибыль организации с целью изучения функционирования системы налогообложения и ее привлекательности для бизнеса, прежде всего внутреннего.

Согласно данным таможни, за 2018 года товарооборот России и Китая вырос на 27\% (им- порт из Китая), а экспорт в Китай со стороны России увеличился на 47\% [7]. Но на данный момент нас интересует то, каким образом функционирует налоговая система Китая в конкретном случае с налогообложением организаций, а также насколько удобно осуществлять внешнеэкономическую деятельность. Одним из соглашений Всемирной торговой организации (членами которой являются Россия и Китай) является Соглашение по техническим барьерам в торговле (далее Соглашение). Согласно ст. 2 Соглашения следует, что «члены обеспечивают, чтобы технические регламенты не разрабатывались, не принимались или не применялись таким образом, чтобы создавать или приводить к созданию излишних препятствий в международной торговле [1].

Рассматривая налогообложение дохода компаний в России и Китае, стоит сразу отметить, что правовое регулирование налога на прибыль организаций в Китае устроено гораздо либеральнее и благоприятнее для бизнеса, чем в России. Налог на доход предприятий в Китае регулируется отдельным законом, как, впрочем, и другие налоги, что, на наш взгляд, является эффективным решением, так как в случае изменения экономических условий региона гораздо проще изменить отдельный закон, который фактически не соотносится с иными статьями единого кодифицированного акта, делая систему налогообложения максимально неповоротливой и неспособной быть готовой к серьезным изменениям.

Итак, согласно Закону Китайской Народной Республики «О налоге на доходы предприятий» от 16 марта 2007 года (далее Закон), Закон определяет основные правила сбора налога на доходы предприятий - корпоративного подоходного налога. Закон определяет круг налогоплательщиков, ставки налога, правила исчисления налога, перечень налоговых льгот. Как следует из положений статьи 2 Закона, плательщиками налога являются резиденты и нерезиденты. Под нерезидентом в данном случае понимаются иностранные предприятия, созданные не на территории КНР, при этом местом фактического управления таких предприятий находятся за пределами КНР. Предприятие имеет структуры или места ведения деятельности на территории КНР либо не имеет их, но источник доходов такого предприятия находится на территории КНР [2].

Привлекательность положения резидентов 
и нерезидентов будут рассмотрена далее. В НК РФ налогообложению компаний посвящена глава 25, которая дифференцирует компании на тех, кто признается налогоплательщиком, и на тех, кто таковым не признается. В частности, к плательщикам налога относятся резиденты. Как следует из п. 5 ст. 246 НК РФ, к налогоплательщикам приравниваются резиденты - российские компании, а также приравненные к российским компаниям иностранные компании, у которых:

1) исполнительный орган (исполнительные органы) организации регулярно осуществляет свою деятельность в отношении этой организации из Российской Федерации;

2) главные (руководящие) должностные лица организации (лица, уполномоченные планировать и контролировать деятельность, управлять деятельностью предприятия и несущие за это ответственность) преимущественно осуществляют руководящее управление этой иностранной организацией в Российской Федерации [6]. При этом резидентами признаются иностранные компании, с которыми правительство России заключило международный договор об избежание двойного налогообложения (пп. 2 п. 1 ст. 246.1 НК РФ).

Особое внимание занимают налоговые льготы, которые в законе Китая имеют отраслевую структуру и направлены на повышение эффективности разработки технологий, а также отраслей, поддерживаемых государством. Согласно ст. 28 Закона КНР о налоге на доходы предприятий, сниженные ставки предполагаются для малорентабельных компаний в размере $20 \%$, а также компании по производству и изготовлению высоких технологий с государственной поддержкой в размере 15\%, что стимулирует развитие промышленности.
В налоговом кодексе России нечто подобное было введено в 2010 году в ст. 145.1 НК РФ, которая освобождает от исполнения обязанности по исчислению и уплате налога на доходы организации. «Освобождение» имеют право получить организации, получившие статус участника проекта по осуществлению исследований, разработок и коммерциализации их результатов в соответствии с Федеральным законом «Об инновационном центре «Сколково», либо участника проекта в соответствии с федеральным законом от 29 июля 2017 года № 216-Ф3 «Об инновационных научно-технологических центрах и о внесении изменений в отдельные законодательные акты Российской Федерации» в течении 10 лет с момента получения статуса. При этом, как следует из п. 2 ранее указанной статьи, такой статус может быть утрачен в случае, если «размер прибыли участника проекта ...превысил 300 миллионов рублей, с 1-го числа налогового периода, в котором произошло превышение указанного совокупного размера прибыли». При этом компания, утратившая право на статус инновационного предприятия, обязана выплатить в бюджет пени.

Делая вывод о привлекательности государств, можно сказать, что в России налоговое законодательство создает значительные трудности, которые в большинстве своем не принимаются иностранными компаниями. В связи с этим, мы считает, что на примере налога на прибыль организаций двух государств можно сделать вывод о том, что лабильности системы должна позволить изменить в том числе и налоговый контроль, порядок взимания налогов и упростить его для вошедших на рынок иностранных компаний.

\section{Библиографический список}

1. Agreement on Technical Barriers to Trade Electronic recourse Data: https://www.wto.org/english/docs_e/ legal_e/17-tbt_e.htm 23.05.2019.

2. Invest in China/Enterprise Income Tax Law of the People's Republic of China. URL: http://www.fdi.gov. cn/1800000121_39_3339_0_7.html Data: 11.06.2019.

3. Афонцев С. Присоединение к ВТО: экономико-политические перспективы. Pro et contra. T. 7., 2002.

4. Генеральное соглашение по тарифам и торговле (ГАТТ 1947 год) от 30 октября 1947 год. СПС «Гарант» Документ опубликован не был. Режим доступа: http://base.garant.ru/2560614/5ac206a89ea76855804609cd950fcaf7 /\#ixzz5pLLpdrhhДата обращения: 29.05.2019.

5. Рейтинг стран по уровню сложности налоговой системы/ Эксперт online. Москва 29.05.2019. URL// https://expert.ru/ratings/table_388484/ Дата обращения: 29.05.2019.

6. Собрание законодательства РФ, 07.08.2000, № 32, ст. 3340. 
7. Товарооборот России и Китая в 2018 году вырос на 27,1\% Электронный ресурс Режим доступа: https://tass. ru/ekonomika/5994096. Дата обращения: 23.05.2019.

8. Шаипова С.А, Тремаскин И.Э. Добросовестность: соотношение в гражданско-правовых и налоговых правоотношениях // Евразийский юридический журнал. 2019. № 4. С. 233-235. 